\title{
UJI EMISI GAS BUANG PEMANFAATAN BAHAN BAKAR PIROLISIS HDPE PADA MOTOR BENSIN 4 TAK 1 SILINDER
}

\author{
Vemby Wiwit Nurahman, Ika Kusuma Nugraheni, Anggun Angkasa B.P \\ Jurusan Mesin Otomotif, Politeknik Negeri Tanah Laut \\ Jl. A Yani Km 6 Pelaihari Tanah Laut Kalimantan \\ Email : vembynurahman@gmail.com
}

Naskah diterima: 22 Nopember 2017 ; Naskah disetujui: 20 Desember 2017

\begin{abstract}
ABSTRAK
Plastik hingga saat ini masih merupakan bahan yang banyak digunakan oleh kalangan industri maupun rumah. Di Indonesia, konsumsi energi di berbagai sektor seperti transportasi, industri dan energi listrik untuk rumah tangga tercatat terus meningkat dengan laju pertumbuhan rata-rata pertahun sebesar 5,2\%, sebaliknya cadangan energi nasional yang semakin menipis menimbulkan kehawatiran akan krisis energi di masa mendatang jika tidak ditemukan sumber-sumber energi yang baru. Pirolisis selain mampu mengolah plastik dengan aman, juga menghasilkan produk cair yang bisa menjadi alternatif sumber bahan bakar. Cairan dari pirolisis digunakan sebagai bahan campuran bahan bakar, setelah diketahui kandungan dari bahan bakar hasil pirolisis kemudian diuji coba menggunakan motor bensin empat tak satu silinder merek Jupiter Z 110 cc tahun pembuatan 2007. Pengujian dilakukan dengan variasi minyak pirolisis dengan bahan bakar premium murni, campuran bahan bakar variasi perbandingan $95 \%$ premium berbanding $5 \%$ biofuel, 90\% premium berbanding 10\% biofuel, $85 \%$ premium berbanding $15 \%$ biofuel, dan $80 \%$ premium berbanding $20 \%$ biofuel. Dengan metode ini di harapkan dapat mengurangi masalah sampah pada lingkungan dan juga dapat mengurangi keutuhan bahan bakar fosil, selain dapat mengurangi masalah sampah pemanfaatan limbah botol plastik ini juga diharapkan dapat menjadi bahan bakar alternatif di masa depan.
\end{abstract}

Kata Kunci: Pirolisis, Sampah Plastik, Emisi Gas Buang

\section{PENDAHULUAN}

Di Indonesia, konsumsi energi di berbagai sektor seperti transportasi, industri dan energi listrik untuk rumah tangga tercatat terus meningkat dengan laju pertumbuhan rata-rata pertahun sebesar 5,2 \%, sebaliknya cadangan energi nasional yang semakin menipis menimbulkan kekhawatiran akan krisis energi di masa mendatang jika tidak ditemukan sumbersumber energi yang baru. Plastik hingga saat ini masih merupakan bahan yang banyak digunakan oleh kalangan industri maupun rumah. Sampah merupakan dua permasalahan besar yang muncul seiring dengan pertumbuhan ekonomi dan pertambahan penduduk.

Padahal saat ini, sekitar 129 juta ton plastik setiap tahunnya diproduksi, dari jumlah tersebut, hampir seluruhnya diproduksi dari bahan minyak bumi. Untuk memproduksi plastik dalam jumlah tersebut dibutuhkan sekitar 12 juta barell minyak bumi pertahunnya. Jumlah ini mencapai $8 \%$ dari jumlah minyak bumi yang dihasilkan. Namun disamping masalah bahan baku yang berasal dari minyak bumi, ada masalah lain berkaitan penggunaan plastik, yaitu plastik merupakan bahan yang susah terurai.

Sejak ditemukan pertama kali pada tahun 1907, penggunaan plastik dan barang-barang berbahan dasar plastik semakin meningkat. Peningkatan penggunaan plastik ini merupakan konsekuensi dari berkembangnya teknologi, industri dan juga jumlah populasi penduduk. Di Indonesia, kebutuhan plastik terus meningkat hingga mengalami kenaikan rata-rata 200 ton per tahun. Tahun 2002, tercatat 1,9 juta ton, di tahun 2003 naik menjadi 2,1 juta ton, selanjutnya tahun 2004 naik lagi menjadi 2,3 juta ton per tahun. Di tahun 2010, 2,4 juta ton, dan pada tahun 2011, sudah meningkat menjadi 2,6 juta ton. Akibat dari peningkatan penggunaan plastik ini adalah bertambah pula sampah plastik. Berdasarkan asumsi Kementerian Lingkungan Hidup (KLH), setiap hari penduduk Indonesia menghasilkan $0,8 \mathrm{~kg}$ sampah per orang atau secara total sebanyak 189 ribu ton sampah/hari. Dari jumlah tersebut $15 \%$ berupa sampah plastik atau sejumlah 28,4 ribu ton sampah plastik/hari (Fahlevi, 2012) [1]. 


\section{TINJAUAN PUSTAKA}

\section{Plastik}

Plastik adalah salah satu jenis makromolekul yang dibentuk dengan proses polimerisasi. Polimerisasi adalah proses penggabungan beberapa molekul sederhana (monomer) melalui proses kimia menjadi molekul besar (makromolekul atau polimer). Plastik merupakan senyawa polimer yang unsur penyusun utamanya adalah Karbon dan Hidrogen. Untuk membuat plastik, salah satu bahan baku yang sering digunakan adalah Naphta, yaitu bahan yang dihasilkan dari penyulingan minyak bumi atau gas alam. Sebagai gambaran, untuk membuat $1 \mathrm{~kg}$ plastik memerlukan $1,75 \mathrm{~kg}$ minyak bumi, untuk memenuhi kebutuhan bahan bakunya maupun kebutuhan energi prosesnya (Kumar dkk., 2011).

\section{Jenis-Jenis Plastik}

Jenis plastik yang dapat didaur ulang diberi kode berupa nomor untuk memudahkan dalam mengidentifikasi dan penggunaannya yaitu sebagai berikut;

\section{PETE/PET (Polyethylene Terephthalate) \\ 2. HDPE (High Density Polyethylene) \\ 3. PVC (Polyvinyl Chloride) \\ 4. LDPE (Low Density Polyethylene) \\ 5. PP (Polypropylene) \\ 6. PS (Polystyrene) \\ 7. OTHER.}

\section{Plastik HDPE}

HDPE adalah High Density Polyethylene yang kuat dan kaku, berasal dari minyak bumi, yang sering dibentuk dengan cara meniupnya. Rumus molekulnya adalah ( $-\mathrm{CH}_{2}-\mathrm{CH}_{2}$-)n. HDPE ini biasanya dapat ditemukan pada botol susu, botol obat, botol shampoo, kemasan juice, botol sabun cair dan botol sabun bayi.

\section{Pirolisis}

Pirolisis berasal dari kata Pyro (Fire/Api) dan Lyo (Loosening/Pelepasan) untuk dikomposisi termal dari suhu bahan organic. Pirolisis merupakan suatu bentuk penguraian bahan organik secara kimia melalui pemanasan tanpa atau sedikit oksigen atau reagen lainnya. Proses pirolisis atau devolatilisasi merupakan proses perengkahan plastik pada suhu tinggi di mulai pada temperatur sekitar $400^{\circ} \mathrm{C}$.

\section{Bahan Bakar}

Bahan bakar yaitu suatu materi apa pun yang dapat di ubah menjadi energi. Umumnya bahan bakar mengandung energi panas yang bisa dilepaskan serta dimanipulasi. Biasanya bahan bakar dipakai manusia lewat sistem pembakaran (reaksi redoks) dimana bahan bakar itu bakal melepaskan panas sesudah direaksikan dengan oksigen di udara.

\section{Emisi Gas Buang}

Emisi gas buang kendaraan berasal dari sisa hasil pembakaran bahan bakar yang tidak terurai atau terbakar dengan sempurna diruang bakar. Unsur yang terkandung dalam gas buang antara lain $\mathrm{CO}, \mathrm{NO}_{2}, \mathrm{HC}$, $\mathrm{C}, \mathrm{H} 2, \mathrm{H} 2 \mathrm{O}$ dan $\mathrm{N}_{2}$, dimana kandungan tersebut banyak bersifat mencemari lingkungan sekitar dalam bentuk polusi udara dan menggangu kesehatan hingga menimbulkan kematian pada kadar tertentu. Pada Negara yang memiliki standar emisi gas buang ada 5 unsur dalam emisi gas buang yang diukur yaitu senyawa $\mathrm{HC}, \mathrm{CO}, \mathrm{CO}_{2}, \mathrm{O}_{2}$, dan senyawa $\mathrm{NO}_{x}$, sedangkan pada Negara yang tidak terlalu ketat hanya mengukur 4 unsur yaitu $\mathrm{HC}, \mathrm{CO}, \mathrm{CO}_{2}$, dan $\mathrm{O}_{2}$.

Dibawah ini adalah table ambang batas gas buang kendraan bermotor lama.

Tabel 1 Ambang Batas Emisi Gas Buang Kendaraan Bermotor Lama.

\begin{tabular}{|c|c|c|c|c|}
\hline \multirow{2}{*}{ Kategori } & \multirow{2}{*}{$\begin{array}{c}\text { Tahun } \\
\text { Pembuatan }\end{array}$} & \multicolumn{2}{|c|}{ Parameter } & \multirow{2}{*}{$\begin{array}{c}\text { Metode } \\
\text { Uji }\end{array}$} \\
\hline & & $\begin{array}{l}\mathrm{CO} \\
(\%) \\
\end{array}$ & $\begin{array}{l}\text { HC } \\
\text { (pp) }\end{array}$ & \\
\hline $\begin{array}{l}\text { Sepeda } \\
\text { motor } 2 \\
\text { langkah }\end{array}$ & $<2010$ & 4,5 & 12000 & Idle \\
\hline $\begin{array}{l}\text { Sepeda } \\
\text { motor } 4 \\
\text { langkah }\end{array}$ & $<2010$ & 5,5 & 2400 & Idle \\
\hline $\begin{array}{c}\text { Sepeda } \\
\text { motor ( } 2 \\
\text { langkah } \\
\text { dan } 4 \\
\text { langkah) }\end{array}$ & $\geq 2010$ & 4,5 & 2000 & Idle \\
\hline
\end{tabular}

Sumber ; Peraturan Mentri Lingkungan Hidup Nomor 05 Tahun 2006

\section{METODOLOGI}

\section{Alat dan Bahan yang Digunakan}

A. Alat Yang Digunakan Alat yang digunakan dalam penelitian ini diantaranya adalah sebagai berikut :

1. Kunci ring pas 10 dan 11.

Digunakan untuk melepas dan memasang baut yang berada pada bagian tutup reaktor pirolisis.

2. Pisau kater

Digunakan untuk memotong paking sel bagian reaktor.

3. Botol plastik.

Digunakan untuk tempat penampungan minyak pirolisis.

4. Multy pegaso.

Digunakan untuk pengujian emisi gas buang.

5. Sepeda motor. 
Digunakan sebagai alat uji coba percampuran bahan bakar.

B. Bahan Yang Digunakan

Adapun bahan yang akan digunakan pada penelitian ini adalah.

1. Botol Plastik HDPE (high density polyethylene) akan dipirolisis dan minyak hasil pirolisis tersebut akan diteliti.

2. Timbangan.

Timbangan digunakan untuk mengukur massa sampah plastik HDPE (high density polyethylene) dan digunakan untuk mengetahui massa minyak pirolisis yang dihasilkan.

3. Kompor gas.

Sebagai tempat nyalanya api.

4. Tabung gas LPG $3 \mathrm{~kg}$.

Tabung gas untuk menampung gas.

5. Selang regulator.

Sebagai penyalura gas menuju kompor.

\section{Prosedur Penelitian Skema Alat}

Adapun prosedur penelitian ini dibagi menjadi beberapa tahap yaitu :

\section{A. Rangkaian Alat Pirolisis}

Adapun prosedur penelitian ini dibagi menjadi beberapa rincian yaitu:

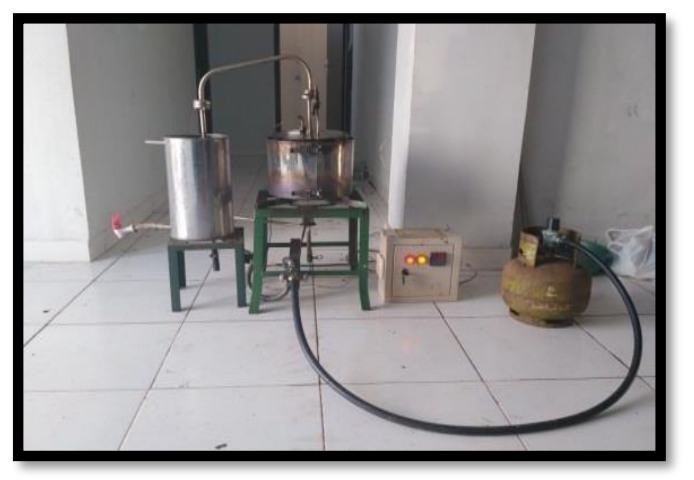

Gambar 1 Alat Uji Emisi.

Keterangan

1. Tabung gas.

2. Selang regulator.

3. Kompor gas.

4. Tabung reaktor pirolisis.

5. Pipa minyak pirolisis.

6. Unit pendingin.

7. Tempat penampung minyak pirolisis.

8. Pipa penyalur air.

Reaktor pirolisis adalah tempat dimana terjadinya proses pirolisis sampah plastik HDPE (high density polyethylene). Plastik yang dimasukkan sudah dalam bentuk potongan-potongan kecil. Proses pirolisis terjadi dengan bantuan pemanas oleh gas LPG.

\section{Persiapan Bahan Limbah Plastik HDPE.}

Pertama botol plastik susu di bersikan dari segala jenis kotoran dengan cara di cuci dengan air, kemudian dicacah sampai ukuran botol susu menjadi kecil-kecil dan dijemur dibawah sinar matahari hingga kering.

\section{Proses Pirolisis}

a. Bahan baku botol plastik susu sebanyak $1 \mathrm{~kg}$ yang sudah dicacah dengan ukuran yang kecilkecil dimasukan kedalam reaktor.

b. Memasang kompor pemanas di bawah reactor.

c. Dilakuakan pemanasa pada suhu kurang lebih $400^{\circ} \mathrm{C}$ sampai semua sampah yang ada didalam raktor terdegredasi dengan sempurna.

d. Dihasilkan gas dan air yang bercampur dengan minyak di pipa pendingin.

Pengujian Karakter Bahan Bakar Hasil Pirolisis.

1. Uji Densitas atau Berat jenis yang di ukur dengan $15^{\circ} \mathrm{C}$, penampilan warna. Hasil pengujian di bandingkan dengan spesifikasi premium 88 yang ditetapkan oleh Dirjen Migas No. 933. K/10/DJM.5/2013.

\section{Uji Emisi Gas Buang}

1. Percampuran Bahan Bakar.

Percampuran bahan bakar ini menggunakan perbandiangan bensin dan biofuel, dari $100 \%$ premium : $0 \%$ biofuel, $95 \%$ premium : $5 \%$ biofuel, $90 \%$ premium : $10 \%$ biofuel, $85 \%$ premium : $15 \%$ biofuel, dan $80 \%$ premium : $20 \%$ biofuel.

2. Multy Pegaso

Multy Pegaso adalah tipe alat yang digunakan untuk pengambilan data emisi yaitu dengan cara sebagai berikut:

a. Nyalakan alat multy pegaso dengan cara hubungkan kelistrik.

b. Putar tombol on off bagian belakang multy pegaso menjadi on, tunggu hingga kuran lebih 2 menit.

c. Nyalakan computer, setelah menyala refresh dahulu computer.

d. Kemudian klik ETS (Emission test sofwere).

e. Apabila ETS sudah terbuka nyalakan alat TEXA.

f. Temptkan kendaraan diposisi rata dan nyalakan mesin kendaraan kurang lebih 5 menit agar suhu engine optimal.

g. Masukan gas probe kedalam mulut kenalpot.

h. Klik search, kemudian klik continue.

i. Akan muncul gasbox com3 dan com5.

j. Atur bagian gasbox com3, kemudian klik exhaust gas analysis, pilih free test.

k. Kemudian akan muncul gas analiser, klik storke diubah menjadi 4, cylinder diubah menjadi 1, dan com diubah menjadi com3.

1. Apabila sudah diatur klik forward. 
m. Akan mucul gas analyser, tunggu hingga membaca apabila kendaraan dinyalakan.

n. Setelah terbaca, klik autozero, klik continuous measurement di tanda ( X ).

o. Lepaskan gas probe dari mulut kenalpot.

p. Matikan alat TEXA denggan menekan tombol off.

q. Refresh kembali computer, klik shut down computer, tunggu hingga computer mati, dan klik tombol off dibagian computer.

r. Putar tombol keposisi off dibelakang multy pegaso dan cabut kabel yang terhubung kelistrik.

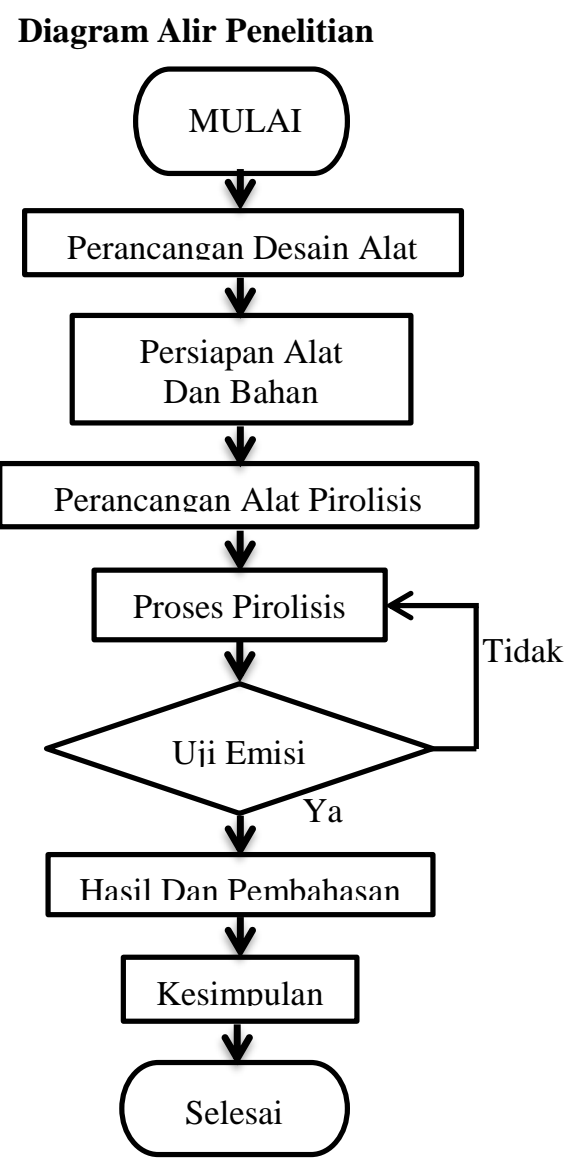

Gambar 2 Diagram Alir Penelitian

\section{HASIL DAN PEMBAHASAN}

\section{Pembuatan Biofuel Botol Plastik}

Pirolisis ini dilakukan dengan menggunakan tabung reaktor berkapasitas $1 \mathrm{~kg}$ dengan menggunakan bahan bakar gas sebagai media pembakaran, dalam percobaan yang telah dilakuakan sebayak 3 kali percobaan jumlah minyak diperoleh $(220 \mathrm{ml})$ pada suhu tertinggi $\left(391^{\circ} \mathrm{C}\right)$, banyaknya jumlah minyak hasil pirolisis dilakukan pengukuran dengan gelas ukur, melalui penyalinan minyak hasil pirolisis dari tempat penampungan minyak pirolisis ke dalam gelas ukur kemudian dilihat ukuran yang tertera pada gelas ukur secara fisual berapa ml minyak yang dihasilkan.

Dalam percobaan pirolisis yang telah dilakukan sebanyak 3 kali percobaan jumlah minyak yang terbentuk disajikan dalam tabel sebagai berikut:

Tabel 2 Minyak Hasil Pirolisis

\begin{tabular}{|c|c|c|c|}
\hline $\begin{array}{c}\text { Percobaan } \\
\text { Ke- }\end{array}$ & $\begin{array}{c}\text { Bahan baku } \\
\text { plastik }\end{array}$ & $\begin{array}{c}\text { Minyak yang } \\
\text { dihasilkan }\end{array}$ & $\begin{array}{c}\text { Suhu } \\
\text { Reaktor }\end{array}$ \\
\hline 1 & $1 \mathrm{Kg}$ & $240 \mathrm{ml}$ & $420^{\circ} \mathrm{C}$ \\
\hline 2 & $1 \mathrm{Kg}$ & $209 \mathrm{ml}$ & $373^{\circ} \mathrm{C}$ \\
\hline 3 & $1 \mathrm{Kg}$ & $211 \mathrm{ml}$ & $380^{\circ} \mathrm{C}$ \\
\hline Rata-rata & $1 \mathrm{Kg}$ & $220 \mathrm{ml}$ & $391^{\circ} \mathrm{C}$ \\
\hline
\end{tabular}

Pada penelitian ini menghasilkan jumlah minyak total sebesar $660 \mathrm{ml}$ dengan rata-rata minyak yang dihasilkan sebesar $220 \mathrm{ml}$ dan suhu rata-rata reaktor $392^{\circ} \mathrm{C}$. Pirolisis plastik HDPE menghasilkan empat produk yang berbeda yaitu: minyak, lilin, gas dan residu. Total minyak yang dihasilkan dari semua proses sebesar $660 \mathrm{ml}$. Reaksi yang terjadi dalam reaktor, pada suhu $200^{\circ} \mathrm{C}$ plastik akan mulai mengalami pelelehan. Pada suhu $300^{\circ} \mathrm{C}$ terjadi perubahan dari cairan menjadi uap. Uap akan keluar melalui kondensor, dan hasil dari kondensor tersebut adalah minyak cair (minyak mentah).

Dari bahan bakar minyak pirolisis ini tidak langsung digunakan sebagaai bahan bakar kendaraan bermotor karena belum diketahui spesifikasi kandungan minyak hasil pirolisis tersebut untuk dilakukan pengujian bahan yang meliputi Densitas dan Warna minyak pirolisis.

Setelah dilakukan pengujian didapatkan hasil sebagai berikut :

\section{Karakter Bahan Bakar Dari Hasil Pirolisis HDPE}

Tabel 3 Karakter Bahan Bakar Pirolisis HDPE

\begin{tabular}{|c|c|c|}
\hline Bahan Bakar & Densitas & Warna \\
\hline Pirolisis HDPE & $0,77 \mathrm{~kg} / \mathrm{m}^{3}$ & Coklat Buram \\
\hline Premium & $0,72 \mathrm{~kg} / \mathrm{m}^{3}$ & Kuning Jernih \\
\hline Standar & $0,71-0,77 \mathrm{~kg} / \mathrm{m}^{3}$ & Kuning jernih \\
\hline
\end{tabular}

Dari karakter bahan bakar hasil pirolisis dapat diketahui densitasnya $0,77 \mathrm{~kg} / \mathrm{m}^{3}$ dan warna coklat buram, sedangkan bahan bakar premium yang digunakan densitasnya $0,72 \mathrm{~kg} / \mathrm{m}^{3}$ dan warnanya kuning jernih, maka dari minyak hasil pirolisis yang digunakan densitasnya $0,77 \mathrm{~kg} / \mathrm{m}^{3}$ masuk dalam bahan bakar standar bensin karena standar bahan bakar mempunyai densitas $0,71-0,77 \mathrm{~kg} / \mathrm{m}^{3}$ tetapi warna 
yang dihasilkan berbeda dengan standar minyak premium, dikarenakan bahan plastik HDPE mempunyai sifat bahan yang kuat dan keras.

Apabila hasil bahan bakar pirolisis diaplikasikan dikendaraan Jupiter $\mathrm{Z}$ dengan perbandingan bahan bakar premium maka mesin kendaraan akan tetap hidup dengan optimal.

\section{Emisi Gas Buang Pemanfaatan Bahan Bakar Pirolisis HDPE}

Adapun emisi gas buang ini dilakukan pada kendaraan Jupiter Z 110 cc Tahun 2007 dengan variasi perbandingan premium murni dengan biofuel dari perbandingan premium $95 \%+$ biofuel $5 \%$, premium $90 \%$ + biofuel $10 \%$, premium $85 \%$ + biofuel $15 \%$, dan premium $80 \%+$ biofuel $20 \%$.

Pengujian dengan percampuran bahan bakar premium dan minyak hasil pirolisis yang dilakukan maksimal 20\%, karena pada penelitian yang pernah dilakukan bahwa percampuran antara bahan bakar premium dan bahan bakar pirolisis yang melebihi $20 \%$ dapat menyebabkan nilai oktan berkurang (Hermanto, 2012).

Untuk menampung bahan bakar premium dengan bahan bakar biofuel tangki dimodifikasi untuk menyalurkan bahan bakar ke ruang bakar.

Tabel 4 Hasil Pengujian Emisi Gas Buang Pada Jupiter Z 110 cc Tahun 2007

\begin{tabular}{|c|c|c|c|c|c|}
\hline $\begin{array}{c}\text { Bahan } \\
\text { Bakar }\end{array}$ & $\begin{array}{c}\mathrm{CO}(\% \\
\text { vol })\end{array}$ & $\begin{array}{l}\mathrm{CO}_{2}(\% \\
\text { vol })\end{array}$ & $\begin{array}{c}\mathrm{HC} \\
(\mathrm{ppm})\end{array}$ & $\begin{array}{c}\mathrm{O}_{2}(\% \\
\text { vol })\end{array}$ & $\begin{array}{c}\lambda(\% \\
\text { vol })\end{array}$ \\
\hline Premium & 4.06 & 3.0 & 465 & 12.7 & 1.90 \\
\hline $\begin{array}{c}\text { Biofuel } \\
5 \% \\
10 \% \\
15 \% \\
20 \%\end{array}$ & 3.42 & 3.1 & 349 & 13.2 & 2.15 \\
\cline { 2 - 6 } & 3.29 & 3.2 & 325 & 13.2 & 2.10 \\
\cline { 2 - 6 } & 3.47 & 3.3 & 361 & 12.9 & 2.11 \\
\hline Standar & Max 1.0 & Min 13.8 & $\begin{array}{l}\text { Max } \\
360\end{array}$ & Max 0.8 & $=1.00$ \\
\hline
\end{tabular}

Pada Tabel 4 menunjukan hasil pengujian penambahan biofuel terhadap premium dengan putaran idle yang menghasilkan emisi gas buang terbaik disetiap varian bahan bakar antara kandungan $\mathrm{CO}$ pada bahan bakar Biofuel 10\% sebesar 3.29\% vol, $\mathrm{CO}_{2}$ pada bahan bakar Biofuel 15\% dan 20\% sebesar $3.3 \%$ vol, HC pada bahan bakar Biofuel 15\% sebesar 325 ppm vol, $\mathrm{O}_{2}$ pada bahan bakar Biofuel 15\% sebesar $12.7 \%$ vol dan lambda pada bahan bakar biofuel $20 \%$ yang mendekati standar sebesar $2.02 \%$ vol.

\section{a. Karbonmonoksida (CO)}

Pada bahan bakar premium murni kandungan $\mathrm{CO}$ yang dihasilkan sebesar $4,06 \%$ kemudian pada campuran premium $95 \%$ + biofuel $5 \%$ kandungan $\mathrm{CO}$ yang hasilnya menurun berada di angka 3,41\% dan pada campuran premium $90 \%+$ biofuel $10 \%$ kandungan $\mathrm{CO}$ menurun, tetapi setelah campuran premium $85 \%$ + biofuel $15 \%$ naik berada angka 3,40\% dan campuran premium $80 \%+$ biofuel $20 \%$ angka naik berada $3,47 \%$.

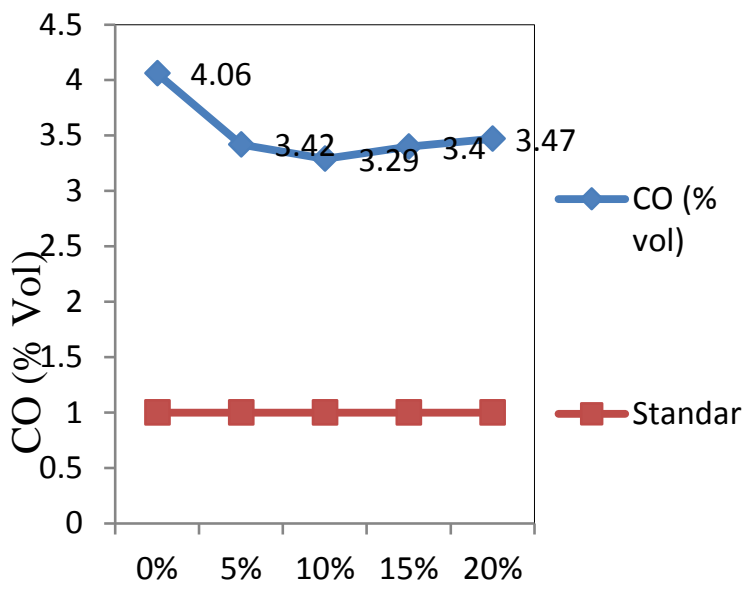

Biofuel (\%)

Gambar 3 Grafik Hasil Emisi CO dalam \% Volume

Dari grafik pada Gambar 3, dapat diketahui bahwa kandungan $\mathrm{CO}$ yang dihasilkan dari campuran antara premium dengan biofuel semakin menurun. Hal ini dimungkinkan karena densitas biofuel yang lebih rendah dibandingkan premium, semakin tinggi berat jenis suatu zat semakin tinggi pula titik didih dan sulit menjadi uap akibatnya bahan bakar semakin sulit bereaksi dengan oksigen, sehingga memerlukan suhu lingkungan yang tinggi untuk terjadi campuran gas dengan oksigen.

Jumlah gas CO yang diperlukan oleh mesin kendaraan dipengaruhi oleh perbandingan antara udara dan bahan bakar yang dihisap oleh mesin ke dalam ruang bakar. Pada saat campuran kaya (kekurangan udara) dan campuran miskin (kelebihan udara), pada emisi gas buang $\mathrm{CO}$ yang campurannya kaya cenderung naik hal ini karena atom karbon yang berasal dari bahan bakar kurang oksigen yang berasal dari udara untuk berkaitan melalui reaksi kimia didalam ruang bakar dan berubah menjadi karbon dioksida. Sedangkan pada campuran miskin (kelebihan udara) konsentrasi $\mathrm{CO}$ berbanding lurus dengan campuran bahan bakar dan udara yang dihisap sehingga konsentrasi $\mathrm{CO}$ akan turun, karena oksigen yang berasal dari udara yang cukup untuk memenuhi reaksi dengan karbon membentuk $\mathrm{CO}_{2}$ (Warju, 2009). 


\section{b. Hidrocarbon (HC)}

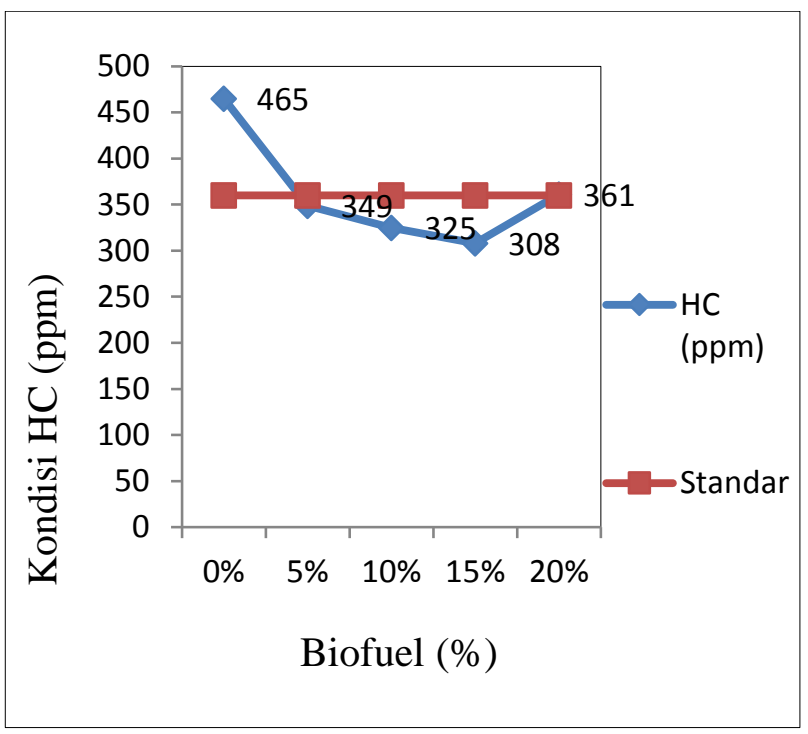

Gambar 4 Grafik Hasil Emisi HC dalam ppm Volume

Dilihat grafik pada Gambar 4, dapat diketahui pada premium murni bahwa kandungan HC sebesar 465 ppm, pada campuran premium $95 \%$ + biofuel $5 \%$ mengalami penurunan HC sebesar 349 ppm, kemudian dengan campuran premium $90 \%$ + biofuel $10 \%$ dan campuran premium $85 \%$ + biofuel $15 \%$ mengalami penurunan yaitu mencapai 325 sampai 308 ppm, berbeda dengan campuran premium $80 \%$ + biofuel $20 \%$ yang mengalami kenaikan tinggi mencapi 361 ppm dengan posisi idle.

Dibandingkan dengan standar Emisi HC maka pada RPM idle setiap percampuran bahan bakar emisi yang dihasilkan cenderung menurun dan di percampuran biofuel $20 \%$ terjadi peningkatan ini membuktikan dengan percampuran bahan bakar biofuel $15 \%$ hasil emisi gas buang yang lebih baik dibanding dengan premium.

HC merupakan gas buang yang diakibatkan bahan yang tidak ikut terbakar. HC merupakan bagian dari bahan bensin yang dilepas ke udara bebas dalam bentuk tidak terbakar atau terpecah dengan tidak sempurna penyebabnya salah satunya adalah turunnya suhu akibat rendahnya bensin.

\section{c. Karbondioksida $\left(\mathrm{CO}_{2}\right)$}

Dilihat grafik pada Gambar 5, pada minyak premium murni dengan campuran premium 95\% + biofuel 5\% menghasilkan $\mathrm{CO}_{2}$ sebesar $3.1 \%$ vol, premium $90 \%+$ biofuel $10 \%$ menghasilkan peningkatan sebesar $3.2 \%$ vol, premium $85 \%+$ biofuel $15 \%$ dan campuran premium $80 \%+$ biofuel $20 \%$ menghasilkan peningkatan yang sama sebesar 3.3 \%vol.

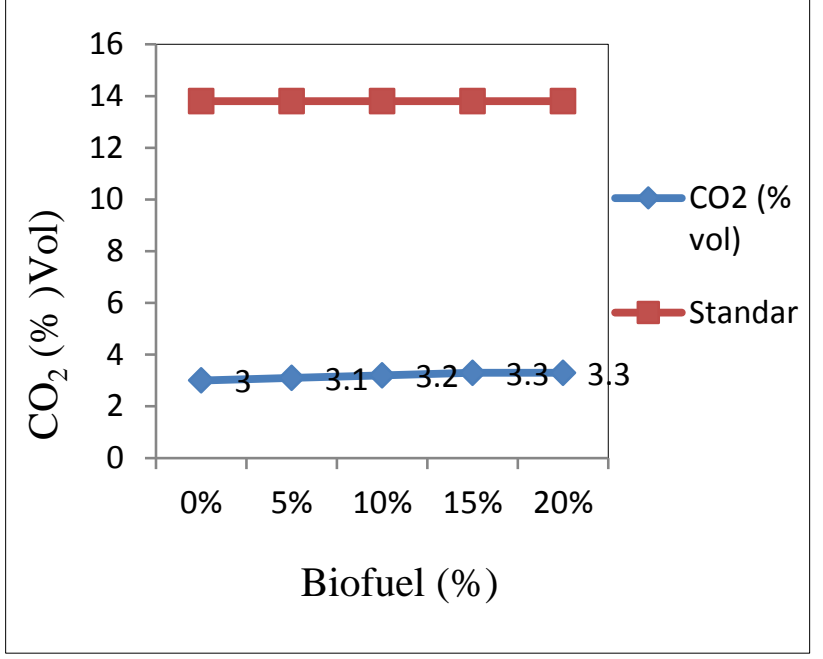

Gambar 5 Grafik Hasil Emisi $\mathrm{CO}_{2}$ dalam \% Volume

Apabila dibandingkan dengan standar internasional maka kandungan $\mathrm{CO}_{2}$ yang dihasilkan dengan penambahan biofuel pada bahan bakar premium maka semua menghasilkan emisi dibawah standar, namun dengan pertambahan biofuel menghasilkan emisi $\mathrm{CO}_{2}$ yang cenderung meningkat sehingga mendekati standar emisi $\mathrm{CO}_{2}$ yang ditetapkan. Pada konstrasi $\mathrm{CO}_{2}$ menunjukan secara langsung pada proses pembakaran diruang bakar. Semakin tinggi $\mathrm{CO}_{2}$ maka pembakaran semakin baik apabila AFR berada pada angka ideal.

\section{d. Oksigen $\left(\mathrm{O}_{2}\right)$}

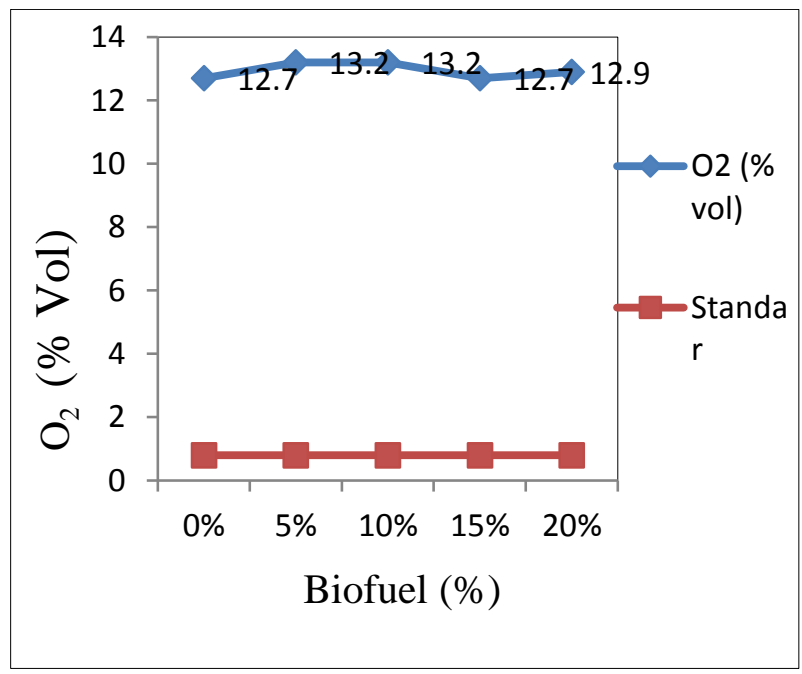

Gambar 6 Grafik Hasil Emisi $\mathrm{O}_{2}$ dalam \% Volume

Konsentrasi kandungan oksigen menunjukan jumlah udara yang masuk ke dalam ruang bakar berbanding dengan jumlah bensin, angka ideal untuk oksigen pada emisi gas buang adalah antara $1 \%$ hingga $2 \%$. Kenaikan angka $\mathrm{O}_{2}$ pada campuran bahan bakar premium $95 \%+$ biofuel $5 \%$, dan campuran premium $90 \%$ + biofuel $10 \%$ mengalami kenaikan yang sama di 
angka $13,2 \%$ sedangkan premium murni berada diangka $12,7 \%$. Penurunan kembali dari campuran premium $85 \%+$ biofuel $15 \%$ dan campuran premium $80 \%$ + biofuel $20 \%$ menjadi angka 12,7 dan $12,9 \%$.

Tingginya data di atas dapat diketahui bahwa kandungan $\mathrm{O}_{2}$ yang dihasilkan campuran premium + biofuel lebih tinggi dibandingkan kandungan $\mathrm{O}_{2}$ pada premium murni, hal ini dikerenakan titik nyala biofuel yang tinggi yaitu $46,50 \%$ sedangkan titik nyala bensin $15^{\circ} \mathrm{C}$ dan pada putaran idle sudut pengapian cenderung mundur dan pembakaran menjadi lambat, sehingga oksigen dan bahan bakar tidak dapat terbakar sempurna karena ada sebagian $\mathrm{O}_{2}$ yang keluar pada saat proses pembuangan.

Pada konsentrasi $\mathrm{O}_{2}$ yang tinggi menunjukan perbandian campuran udara terhadap bahan bakar (AFR) yang terlalu kaya, kondisi ini dapat disebabkan oleh:

- AFR yang tidak tepat.

- Kebocoran pada saluran intake.

- Kegagalan pada sistem pengapian sehingga menyebabkan pembakaran pada ruang bakar tidak optimal.

\section{e. Lambda $(\lambda)$}

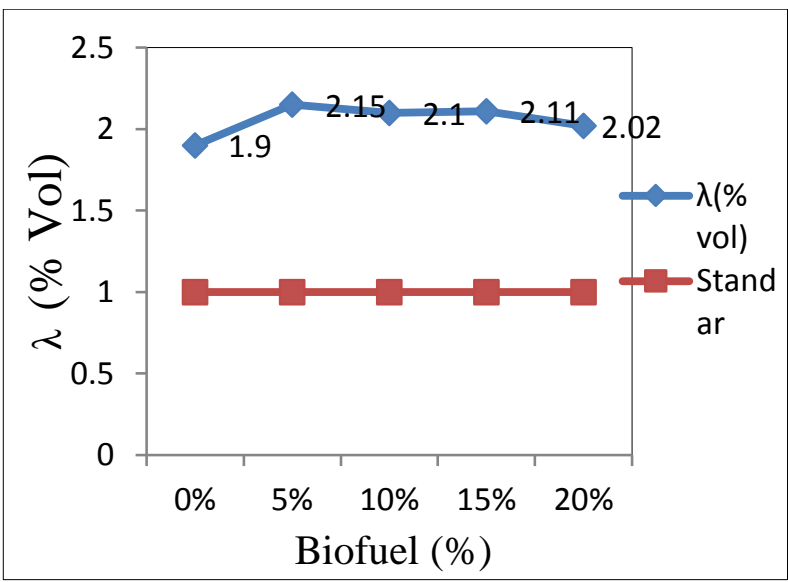

Gambar 7 Grafik Hasil Emisi Lambda dalam \% Volume

Pada Gambar 7 Menunjukan besarnya nilai lambda di setiap perbandingan setiap putaran idle. Pada bahan bakar $0 \%$ sampai bahan bakar 5\% mengalami peningkatan lambda dan mengalami penurunan di bahan bakar $10 \%$, pada variasi bahan bakar $15 \%$ dan $20 \%$ mengalami kenaikan dan penurunan lambda. Apabila dibandingkan dengan standar internasioal emisi lambda maka belum mencapai standar emisi, namun dengan semakin tinggi perbandingan biofuel maka konsentrasi akan mendekati standar lambda berada pada $20 \%$ yaitu sebesar $2.02 \%$ vol. grafik di atas menunjukan semakin banyak percampuran bahan biofuel maka nilai lambda semakin menurun, tingginya nilai lambda menunjukan campuran terlalu kurus karena homogenitas campuran bahan bakar.

\section{KESIMPULAN}

Dari penelitian yang sudah dilakukan pada proses pirolisis sampah plastik menjadi minyak, maka dapat diambil beberapa kesimpulan sebagai berikut:

1. Dari hasil percobaan yang dilakuan sebanyak 3 kali dapat diketahui reaktor pirolisis yang mempunyai kapasitas $1 \mathrm{~kg}$ dengan bahan baku botol plastik HDPE (High Density Polyethylene) dapat menghasilkan minyak hasil pirolisis dengan jumlah rata-rata sebanyak 220 $\mathrm{ml}$, hasil minyak pirolisis mempunyai karakter yang mendekati standar bahan bakar dengan densitas pirolisis $0,77 \mathrm{~kg} / \mathrm{m}^{3}$, dan warna coklat buram.

2. Pada perbandingan premium $85 \%$ : biofuel $15 \%$ pada posisi idle masih berada di bawah ambang batas gas buang bermotor ( $\mathrm{CO} 4,5 \%$ vol dan $\mathrm{HC}$ 2400 ppm) yaitu CO 3,47 \%vol dan HC 308 ppm.

\section{SARAN}

Dari pelaksanaan dan pengerjaan Tugas Akhir ini ada beberapa saran yang dapat diberikan antara lain:

1. Dalam penelitian berikutnya, perlu adanya memodifikasi bagian reaktor untuk mempermudah pengambilan arang atau sisa pembakaran yang ada di dalam reaktor.

2. Alat yang ada memiliki aliran uap yang panjang, sehingga perlu dipendekkan untuk mengurangi waktu pirolisis.

\section{DAFTAR PUSTAKA}

[1] Pahlevi, M.R., 2012, Sampah Plastik (file:///I:/Artikel\%20plastic\%20to\%20o il/twitsampah-plastik.html)

[2] Budi, S U., 2013. Berbagi Metode Konversi Sampah Plastik Menjadi Bahan Bakar Minyak. Jurnal Teknik Vol.3 No 1.

[3] Fajri, M N., 2013 Pembuatan Fuel Dari Liquid Hasil Pirolisis Plastik Polipropilen Melalui Proses Reforming Dengan Katalis. Jurnal Teknik Pomits Vol. 2 No 2.

[4] Fauji, M., 2015. Pengaruh Bioetanol Terhadap Lambda Dan Emisi Gas Buang Pada Sepeda Motor Empt Tak Satu Silinder Berbahan Bakar Premium. Skripsi Fakultas Teknik Universitas Negeri Semarang.

[5] Norsujianto, T., 2014. Unjuk Kerja Dan Emisi Gas Buang Motor Diesel Menggunakan Bahan Bakar Campuran Minyak Hasil Pirolisis Limbah Plastik Dan Biosolar Sebagai Bahan Bakar Alternatif. Jurnal Teknologi Dan Industri Vol.3 No 1. 
[6] Nurdianto, P., 2016. Pengujian Bahan Bakar Biofuel Hasil Pirolisis Botol Plastik Pada Sepeda Motor.

[7] Pertiwi, R., 2015. Pengaruh Penggunaan Katalis Zeolit Alam Dalam Pirolisis Limbah Plastik Jenis Hdpe Menjadi Bahan Bakar Cair Setara Bensin.

[8] Santoso, S., 2010. Uji Sifat Minyak Pirolisis Dan Uji Performasi Kompor Berbahan Bakar Minyak Pirolisis Dari Sampah Plastik. 